\title{
GLL
}

a

Geomatics, Landmanagement and Landscape No. $2 \cdot 2019,165-174$

\section{THE SCOPE OF EXAMINATION OF THE REAL ESTATE APPRAISAL REPORT IN COURT OF LAW AND IN ADMINISTRATIVE PROCEEDINGS - SELECTED PROBLEMS ILLUSTRATED WITH THE JURISPRUDENCE OF THE SUPREME COURT, COURTS OF GENERAL JURISDICTION, AND ADMINISTRATIVE COURTS}

\author{
Maria Zbylut-Górska, Adam Górski
}

\begin{abstract}
Summary
The article presents considerations regarding the practical problem of the scope of the examination or verification of the real estate appraisal report by the court of justice or by an administrative body.

Based on the analysis of administrative courts' judgements or decisions, it should be stated that there is no uniform view developed in the jurisprudence of this issue. Various standpoints in this matter can be observed: from the position limiting the possibility of examining the report to formal issues only, to the position allowing the possibility of far-reaching interference with its substantive content (for instance, in the choice of approach, or valuation methods). The judgements of the Supreme Court and common courts demonstrate an approach to the problem allowing free discretionary assessment of evidence, without referring to specific issues regarding the assessment of the content in either substantive (content-related) or formal terms. In the opinion of the present authors, it is necessary to distinguish between the verification of the appraisal report in terms of objective criteria from the examination in the scope of subjective criteria.
\end{abstract}

\section{Keywords}

real estate appraisal report - real estate property appraiser $\bullet$ examination (verification) of the appraisal report

\section{Introduction}

A property appraiser plays a significant role in the process of determining the value of real estate. The document presenting the proceedings, as a result of which the property value is determined, is the real estate appraisal report, the scope, content and form of which are regulated, among others through the Act on Real Estate Management [1] (UoGN) and the Regulation by the Council of Ministers on property valuation and the elaboration of a real estate appraisal report [2] (RWN). 
Appraisal reports are commonly used, inter alia, in court and administrative proceedings. In criminal, civil and administrative proceedings alike, in many situations, the courts and administrative authorities have to evaluate real estate property. Real estate appraisal undoubtedly requires specialist knowledge and therefore an expert is consulted in the field of real estate appraisal. That expert elaborates an opinion - an appraisal report, according to the commission. In many cases, such reports are questioned by the parties to the proceedings (see, for example, [3] Werner 2014), and that requires from the court and administrative authorities that they would settle the allegations.

Therefore, a question should be asked, to what extent the court of law or another authority (also on the basis of requests by the parties), while not having specialist knowledge in the field of real estate appraisal, are able to assess the substantive content of the appraisal report.

In order to find an answer to the question posed, numerous rulings of the Supreme Court, common courts, and administrative courts were analysed.

\section{The scope of studying the real estate appraisal reports in the light of jurisprudence}

Referring to the views formulated in the jurisprudence of administrative courts, it should be pointed out that some of these rulings emphasize that the body that does not have specialist knowledge in the field of real estate appraisal should limit itself to examining the appraisal report in formal terms, that is, to verify whether it was prepared and signed by an authorized person, whether it contains elements of content required by law, and whether it does not contain ambiguities, mistakes or deficiencies, which should be corrected or supplemented so that the document would have evidential value [4] (Judgement by the WSA 2012). In the light of these views, evaluation of the appraisal report by the administrative body is not possible in so far as it would concern specialist knowledge. Pursuant to Article 154 of the UoGN, the real estate property appraiser decides about the choice of approach, method and technique of property appraisal. It is also and only the appraiser who decides about the selection of real estate that he or she adopts for comparison [5] (Judgement of the Supreme Administrative Court 2014), [6] (Judgement of the WSA 2018), [7] (Judgement of the WSA 2018). Limiting the verification of the appraisal report to formal issues is undoubtedly in line with the postulates of real estate property surveyors [8] (Position of SRM 2015). An uncritical adoption of the above view could lead to the necessity of basing the court's decision in the given case on the appraisal reports, which after their analysis seem to be incorrect, but nevertheless they meet all the formal conditions. In view of the foregoing, the case law postulates the need to distinguish the verification of the evidential credibility of the appraisal report from the verification of the correctness of that appraisal report. The assessment of the correctness of the appraisal report belongs to the professional organization of real estate property appraisers. Undermining the valuation method, the reliability of adjustment coefficients used in the given appraisal, or properties 
adopted for comparison, may take place as part of this assessment carried out by the aforementioned organization [9] (Judgement of the NSA 2017), [10] (Judgement of the WSA 2018), [11] (Judgement of the WSA 2018). The indicated approach gives the court or the administrative body a complete discretion to assess the piece of evidence, which the appraisal report constitutes. Formally, without interfering with the substantive evaluation of the property appraiser's work, the court may consider the appraisal report to be unreliable (unconvincing) and admit evidence from the opinion issued by another expert. Of course, from the formal point of view, such an assessment may not be considered as questioning the regularity or correctness of the real estate appraisal report itself. Thus, it should be recognized that even a correct appraisal report might be considered unreliable. Such a situation will arise, in particular, if the property appraiser is unable to explain any doubts that have been raised and reported to the given authority, which conducts the proceedings.

In the next group of judgements, we can find a certain development of the above view, and the admission of a possibility - or even an obligation of the court or the authority conducting the proceedings - to verify the correctness of the appraisal report. And so, it is emphasized that the real estate appraisal report is an expert opinion, which is subject to evaluation not only in formal terms, but also in material terms, that is regarding its content. Both the administrative body and the court that is hearing the case are obliged to assess the evidential value of the appraisal report. At the same time, this applies to the approach as well as the value estimation methods and techniques adopted by the property appraiser. This is because the fact that the choice of those methods belongs to the appraiser does not mean that he or she can act arbitrarily. Only such appraisal report that satisfies formal conditions, and is also based on the correct data on the real estate property being estimated, correct selection of similar (comparable) real estate properties, and correct recognition of features that differentiate these properties from the real estate under valuation, as well as proper determination of adjustment coefficients, may be the foundation for adjudging the given case [12] (Judgement of the NSA 2012), [13] (Judgement of the WSA 2013), [14] (Judgement of the WSA 2018), [15] (Judgement of the NSA 2012). The prohibition of substantive interference in the appraisal study is understood very narrowly. It is emphasized that the statement that the administrative body can not interfere with the substantive legitimacy of the opinion issued by a real estate property expert should be understood in such a way that the administrative authority can not - instead of a property appraiser and contrary to his opinion - assume that the value of the real estate property is different than the appraiser had assumed [16] (Judgement of the SAC 2018), [17] (Judgement WSA 2018).

Regardless of the indicated possibilities, or even a substantive obligation to assess the appraisal report, in case law we can even find clear indications as to the desired valuation method. And so, in a judgement of 9 May 2018, the Regional Administrative Court based in Gdańsk indicated that in using the comparative approach, the average price adjustment method was preferred to the pair comparison method [18] (Judgement of the WSA 2018). 
Based on the presented rulings, it should be noted that there is no uniform view developed in the jurisprudence of administrative courts regarding the scope of the examination of the real estate appraisal report. Thus, various positions in this regard can be observed: from the position limiting the possibility of verification the appraisal report to formal issues only, to the position allowing the possibility of far-reaching interference in its content. The first position is undoubtedly beneficial for real estate appraisers and the latter virtually completely limits the independence of the appraiser and is in fact contrary to the law (see: Article 154 of the UoGN [1]).

When analysing the views developed in the jurisprudence of common courts, it should be stressed that it is unquestionable that the real estate appraisal report is one piece of the evidence in a case that is subject to examination by a court, and just like any other evidence, it is subject to a free discretionary assessment (for an exception, see for instance [19] Article 11 of the Civil Code). The jurisprudence of common courts indicates that the courts hearing the case have full free discretion in assessing the credibility of the evidence, which also applies to expert evidence [20] (Decision of the SN 2018). It is also emphasized that the assessment of the evidence in the form of an expert opinion is available only to the court, and that the court is not allowed to rely on other entities in this matter [21] (Judgement of the SA 2018).

The rulings of common courts demonstrate a look at the problem from the perspective of free discretionary assessment of evidence, and the failure to refer to specific issues regarding the assessment of the real estate appraisal report in terms of content or form. The view presented in the common judiciary is similar to the already quoted view of administrative courts, indicating the need to distinguish the assessment of the evidential credibility of the appraisal report from the assessment of the correctness of that report.

Both in the rulings of the Supreme Court, common courts and administrative courts, it is indicated that in case of doubts as to the expert's opinion regarding the estimation of the real estate property, the court may request explanations or supplements, admit evidence from another expert's opinion, or use the control route provided for in Article 157 section 3 of the UoGN (see for instance [22] Order of the SN 2018, [23] Judgement of the Supreme Court 2003, [24] Judgement of the SAC 2018).

Recognizing the problem of the scope of real estate appraisal report verification, it was specifically pointed out in the doctrine that the borders are blurring between the assessment of the appraisal report in terms of coherence and logic, and interference in the sphere of methodology and specialist knowledge of the appraiser due to the questioning of the selection of the so-called comparative real estate properties and determination of adjustment coefficients [25] (Jaworski et al. 2017).

The indicated problem is very complex because on the one hand the appraiser has some free discretion in choosing, for instance, the similar real estate properties for comparison, and in principle, in determining which real estate properties are similar to the one being valuated, and on the other hand, there is a striving to determine the property value objectively, and thus to eliminate the subjective factor that is the personal opinion of the given appraiser (see for instance [26] Łopato 2018). In some situations, 
the law limits the free discretion of the appraiser (see for instance [2] $\$ 28 \mathrm{RWN}$ ). In such cases, it is difficult to require the court not to challenge the report if the court finds that the applied method of valuation is inconsistent with applicable law.

The administrative courts, following the Supreme Administrative Court, indicate that the real estate appraisal report should contain data necessary to assess its reliability and, at the same time, quote the circumstances necessary to assess the adequacy of the report to the circumstances of the case (see [27] Judgement of the SAC 2008). In order to avoid a plea of arbitrary action, the appraiser should justify his choices in the appraisal report [28] (Judgement of the SAC 2008). The real estate appraisal report must explain why the appraiser made these and not other choices and determinations, and the wording in this respect must be verifiable by the court, the administrative body, and the parties involved [29] (Judgement of the NSA 2017), [30] (Judgement of the WSA 2018).

\section{Proposed solution to the problem of the scope of real estate appraisal reports verification}

The literature postulates the introduction of the widest possible verification of real estate appraisal reports [25] (Jaworski et al. 2017). The introduction of audits of the appraisal reports with virtually no restrictions may lead to effective questioning in principle of each report, which is not consistent with the expectations of the party. In our opinion, one should distinguish the verification of the appraisal report in terms of objective criteria from control over subjective criteria. Objective criteria might include, for example, the compliance of the report with the applicable regulations, its completeness, compliance with formal conditions, compliance of the adopted comparable properties with the actual state (for instance, it would be incorrect to compare a land property developed with a single-family building with a plot of land developed with a multi-family building; or a plot intended in the local plan for single-family housing development with a plot intended for afforestation, etc.) In general, this encompasses all the criteria that can be unambiguously classified on a true-false basis. Subjective criteria are those criteria that are covered by the freedom of choice by the expert, for instance, selection of similar properties for comparison (from among similar properties appropriately classified according to the objective criteria), choice of characteristic features, determination of their weights, etc. Basically, we should opt for the full possibility of verifying the objective criteria, and limiting the control of any subjective criteria. Regarding subjective criteria, one should not exclude total control, and only limit it to cases including gross faults or errors. However, such cases cannot be precisely defined, as they will be identified on the basis of a specific appraisal report.

This problem is analogous to the question of issuing various judgements by common courts in similar cases. Legal provisions in many cases give the court a considerable margin of freedom, for example in the field of adjudging on the amount of compensation for the death of a relative, for detriment to health, etc. In the jurisprudence of the Supreme Court and common courts, it is indicated that the individual character of the compensation for the harm suffered determines what specific amount is "appropriate" 
and whereas that essentially belongs to the sphere of free discretionary decision by the judges, that decision cannot be arbitrary [31] (Judgement of the SN 2008), [32] (Judgement of the SA 2012).

In other judgements, it is emphasized that since the determination of the amount of compensation is extremely evaluative and belongs to the sphere of the judge's free discretion, the interference of the appellate court in the amount of compensation determined in the sentence is possible only if all the circumstances of the case affecting its size are taken into account and proven disproportionately inappropriate (that is to say, grossly excessive or abnormally low) [33] (Judgement of the SA 2015).

The adoption of similar principles will also be desirable in the scope of the examination of appraisal reports. Challenging the subjective views of the appraiser will lead to the situation that it would be possible to effectively undermine virtually each real estate appraisal report. Effective questioning of the report will ultimately lead to the admission of evidence from the next report, which it would also be possible to question on the same grounds. The above considerations are not purely theoretical because, in practice, problems arising from the presence of more than one appraisal reports used in the same case have already been observed.

And so, for example, the District Court in Bytom settled the case for payment for the non-contractual use of a real estate property. According to the opinion prepared by a property appraiser at the plaintiff's request, the amount of remuneration for noncontractual use of the real estate in the period from 1 to 31 August 2013 was set at PLN 7062.68, with estimates made using the income-based approach, applying the investment method (simple net capitalization method). The respondent presented the opinion of a real estate property appraiser, according to which the rent for the real estate that could have been obtained in the period covered by the claim was PLN 1711.30. Another expert appointed by the court estimated the income that could have been obtained from the property in question at PLN 3318. In the case at hand, two opinions were submitted regarding the average rent for a period of one month, but these concerned a different period, that is, the year 2011. Both opinions were prepared by court-mandated experts. In the first opinion, the rent amount was determined as PLN 2028.23, and in the second, as PLN 3589.28. [34] (Judgement of the SR 2015). Undoubtedly, in the aforementioned case, there were significantly divergent opinions, and the court had to make a choice. It should be noted that - contrary to appearances - the choice is not to adopt the right opinion, but only to decide whether to admit evidence from the next expert opinion. In the case at hand, the court stressed that the evidence of an expert opinion within the meaning of article $278 \mathrm{KPC}$ [19] is only the opinion made at the court's behest. Opinions prepared at the commission of the parties are private opinions, and their content may constitute evidence from a private document. On the other hand, opinions prepared for the needs of other proceedings and concerning the year 2011 do not contain conclusions that would refer directly to the claim being the subject of the current proceedings, hence they constituted a kind of reference point for the court, allowing the assessment of evidence from expert opinion and, consequently, resolving the dispute between the parties [34] (Judgement of the SR 2015). 
In the judgements of administrative courts, we can find statements saying that the party questioning the appraisal report should submit to the anti-claim (a counter report), including the opinion of the professional organization of property appraisers, or provide circumstances indicating significant doubts about the reliability of the extant report [35] (Judgement of the WSA 2018), or possibly provide another expert's opinion [36] (Judgement of the WSA 2017). However, the judgements should not be interpreted in such a way that in the case of developing, for example, a counter report, the authority or court would be obligated to admit evidence from the opinion of another expert. The first step is to admit evidence from the supplementary opinion of the original expert, in order to address the allegations raised or the discrepancies observed. It is only in the absence of satisfactory answers that the authority should admit evidence from another expert's opinion. In the situation of immediate admission of evidence from another expert, the authority would find itself in the position of having many appraisal reports, among which it would have to choose the right one. Making such a choice correctly - without specialist knowledge and without making a comprehensive verification of the submitted appraisal reports - seems very much doubtful, or at least burdened with a high risk of making a mistake. One solution may be to use the abovementioned possibility of verifying the real estate appraisal report by a professional organization [1] (Article 157 of the UoGN).

However, the result of such verification would in principle be useful if one of the appraisal reports was found to be defective. If the validity of the two appraisal reports were to be confirmed, the situation of the court or the authority would become even more complicated. It should be noted that a negative opinion of a professional organization is not binding. As a result of an amendment made in 2017 to article 157 UoGN [1], the negatively assessed appraisal report does not lose the substantial character of an opinion about the value of real estate. However, the opinion on the part of a professional organization is undoubtedly a valuable suggestion for the authorities and courts in terms of evaluation of the appraisal report [37] (Judgement of the WSA 2018).

For this reason, allowing the expert to respond to the allegations presented is tremendously significant, because only after the expert's explanation it is possible to make a comprehensive evaluation of the appraisal report along with the supplementary opinion, and to make a decision regarding the necessity of appointing another expert or lack thereof. In the case of admitting the evidence from the opinion of the next expert, the court of the authority has indeed two reports, but one of these has been considered unsuitable - due to, for example, lack of a logical explanation of the doubts that had been raised, or lack of proper supplementation. In this respect, there is a free assessment of the evidence, which, however, is not an arbitrary assessment - due to the fact that the authority must duly justify its decision.

However, one can not share the opinion that the principle of free assessment of evidence in relation to appraisal reports can be implemented only to a limited extent, that is, not exceeding the sphere of special knowledge of property appraisers [38] (Drobyszewska 2018). 


\section{Conclusions}

The court and administrative authorities must always be able to react to gross errors in the real estate property appraisal report. An appraisal report does not differ in this respect from the opinion of any other kind of expert, and it would be difficult to find arguments why only this one special field should be subject to any exception in the scope of the free or discretionary assessment of evidence. As we have stressed, the opinion of a particular expert, despite being based on special knowledge, may be unconvincing. And as the Supreme Administrative Court emphasized in the aforementioned ruling of 12 December 2017 [10], the assessment of the evidential credibility of the appraisal report should be distinguished from the assessment of the correctness of that report. Moreover, the court is responsible for the outcome of the proceedings - therefore, it is not possible to deprive the court of the possibility of a free discretionary assessment of any evidence, including the evidence from the real estate appraisal report.

The limitation of the principle of the discretionary assessment of evidence, suggested in the subject literature, in relation to the appraisal reports would restrain all participants in the proceedings, preventing them from a proper explanation of the case. It should be emphasized, however, that in the case of a coherent and convincing opinion, in relation to which allegations were raised only in the scope of elements covered by the expert's discretion, admission of evidence from subsequent experts is, as a rule, meaningless as a questioning of a credible appraisal report. It is the authors' opinion that it is essential to distinguish between the verification of the appraisal report in terms of objective criteria and the verification in the scope of subjective criteria. At the same time, we should opt for the full possibility of verifying the objective criteria, while limiting the verification of subjective criteria. Regarding subjective criteria, one should not exclude verification altogether, but rather limit it to cases of gross faults. This scope of the appraisal report verification, on the one hand, does not restrict the authorities conducting the proceedings because it allows them to assess every piece of evidence presented in the case, and on the other hand, it limits this control in the case of subjective criteria to the cases of gross errors, which takes into account the specificity of the profession of real estate property appraiser, and the discretionary freedom of real estate valuation granted to him by law.

\section{References}

[1] Ustawa z dnia 21 sierpnia 1997 r. o gospodarce nieruchomościami, Dz.U. Nr 115, poz. 741 z późn. zm.

[2] Rozporządzenie Rady Ministrów z dnia 21 września 2004 r. w sprawie wyceny nieruchomości i sporządzania operatu szacunkowego, Dz.U. Nr 207, poz. 2109 z późn. zm.

[3] Werner W.A. 2014. Mankamenty „rynku” rzeczoznawców majątkowych. Nieruchomości, 4, Legalis.

[4] Wyrok Wojewódzkiego Sądu Aadministracyjnego w Warszawie z dnia 24 kwietnia 2012 r., I SA/Wa 1972/11, http://www.orzeczenia-nsa.pl

[5] Wyrok Naczelnego Sądu Administracyjnego z dnia 7 marca 2014 r. I OSK 1894/12, Legalis. 
[6] Wyrok Wojewódzkiego Sądu Administracyjnego w Łodzi z dnia 5 grudnia 2018 r. II SA/Łd $606 / 18$, Legalis.

[7] Wyrok Wojewódzkiego Sądu Administracyjnego w Łodzi z dnia 5 grudnia 2018 r. II SA/Łd $607 / 18$, Legalis.

[8] Stanowisko Rady Krajowej Polskiej Federacji Stowarzyszeń Rzeczoznawców Majątkowych w sprawie granic weryfikacji przydatności dowodowej operatów oraz wykładni pojęcia wiedzy specjalnej rzeczoznawcy majątkowego z dnia 23 marca 2015 r. http://www.srm.com.pl/

[9] Wyrok Naczelnego Sądu Administracyjnego z dnia 12 grudnia 2017 r. II OSK 746/17, Legalis.

[10] Wyrok Wojewódzkiego Sądu Administracyjnego w Białymstoku z dnia 29 listopada 2018 r. II SA/Bk 561/18, Legalis.

[11] Wyrok Wojewódzkiego Sądu Administracyjnego w Gdańsku z dnia 18 lipca 2018 r. II SA/ Gd 260/18, Legalis.

[12] Wyrok Naczelnego Sądu Administracyjnego z dnia 18 stycznia 2012 r. I OSK 961/11, Legalis.

[13] Wyrok Wojewódzkiego Sądu Administracyjnego w Krakowie z dnia 4 lipca 2013 r. II SA/ Kr 1673/12, Legalis.

[14] Wyrok Wojewódzkiego Sądu Administracyjnego w Poznaniu z dnia 12 grudnia 2018 r. IV SA/Po 918/18, Legalis.

[15] Wyrok Naczelnego Sądu Administracyjnego z dnia 31 stycznia 2012 r. I OSK 2085/11, Legalis.

[16] Wyrok Naczelnego Sądu Administracyjnego z dnia 17 maja 2018 r. I OSK 1590/16, Legalis.

[17] Wyrok Wojewódzkiego Sądu Administracyjnego w Białymstoku z dnia 10 maja 2018 r. II SA/Bk 156/18, Legalis.

[18] Wyrok Wojewódzkiego Sądu Administracyjnego w Gdańsku z dnia 9 maja 2018 r. II SA/ Gd 104/18, Legalis.

[19] Kodeks postępowania cywilnego z dnia 17 listopada 1964 r. (Dz.U. Nr 43, poz. 296 z późn. $\mathrm{zm})$.

[20] Postanowienie Sądu Najwyższego - Izba Cywilna z dnia 31 sierpnia 2018 r. II CSK 191/18, Legalis, www.sn.pl

[21] Wyrok Sądu Apelacyjnego w Poznaniu - I Wydział Cywilny z dnia 12 lipca 2018 r. I ACa 1409/17, www.orzeczenia.ms.gov.pl, Legalis.

[22] Postanowienie Sądu Najwyższego - Izba Cywilna z dnia 10 września 2018 r. II CSK 205/18 Legalis, www.sn.pl

[23] Wyrok Sądu Najwyższego - Izba Karna z dnia 4 lutego 2003 r. III KKN 494/00, Legalis.

[24] Wyrok Naczelnego Sądu Administracyjnego z dnia 21 lutego 2018 r. II OSK 1070/16, Legalis.

[25] Ustawa o gospodarce nieruchomościami. Komentarz Jacek Jaworski, Arkadiusz Prusaczyk, Adam Tułodziecki, Marian Wolanin 2017, komentarz do art. 157, Legalis.

[26] Łopato J. 2018. Statystyka w wycenie nieruchomości - refleksje pokonferencyjne. Nieruchomości, 5.

[27] Wyrok NSA z dnia 8 lutego 2008 r. II OSK 2012/06, Legalis.

[28] Wyrok NSA z dnia 6 czerwca 2008 r. I OSK 852/07, Legalis.

[29] Wyrok NSA z dnia 26 lipca 2017 r. I OSK 2665/15, Legalis.

[30] Wyrok Wojewódzkiego Sądu Administracyjnego w Krakowie z dnia 17 lipca 2018 r. II SA/ Kr 745/18 OSG 2019 Nr 1, poz. 3, Legalis.

[31] Wyrok Sądu Najwyższego - Izba Karna z dnia 4 lutego 2008 r. III KK 349/07, Prok. i Pr. 2008 Nr 7-8, poz. 28; KZS 2008 Nr 5, poz. 64; Biul. SN Pr. Kar. 2008 Nr 4; OSNwSK 2008 $\mathrm{Nr}$ 1, poz. 295, Legalis. 
[32] Wyrok Sądu Apelacyjnego w Łodzi - I Wydział Cywilny z dnia 16 listopada 2012 r. I ACa 798/12, www.orzeczenia.ms.gov.pl, Legalis.

[33] Wyrok Sądu Apelacyjnego w Łodzi z dnia 6 lipca 2015 r. I ACa 67/15, Legalis.

[34] Wyrok Sądu Rejonowego w Bytomiu z dnia 28 lipca 2015 r. I C 836/14, http://orzeczenia. bytom.sr.gov.pl

[35] Wyrok Wojewódzkiego Sądu Administracyjnego w Poznaniu z dnia 6 kwietnia 2018 r. II SA/Po 1031/17, Legalis.

[36] Wyrok Wojewódzkiego Sądu Administracyjnego w Białymstoku z dnia 28 marca 2017 r. II SA/Bk 58/17, Legalis.

[37] Wyrok Wojewódzkiego Sądu Administracyjnego w Gorzowie Wlkp. z dnia 19 września 2018 r. II SA/Go 496/18, Legalis.

[38] Drobyszewska M. 2018. Prawidłowość operatu szacunkowego a spór o wartość nieruchomości. Nieruchomości, 10, Legalis.

Dr inż. Maria Zbylut-Górska

Uniwersytet Rolniczy w Krakowie

Katedra Geodezji

30-149 Kraków, ul. Balicka 253a

e-mail: m.zbylut-gorska@urk.edu.pl

ORCID: 0000-0003-4436-8248

Dr Adam Górski, adwokat

30-225, Kraków, al. Panieńskich Skał 2

e-mail: m.zbylut-gorska@urk.edu.pl 